\title{
DEVELOPMENT AND DESCRIPTION OF LIGHT FUNCTIONAL DULCE DE LECHE WITH COFFEE
}

\author{
Desenvolvimento e descrição de doce de leite light funcional com café \\ Ívina Catarina de Oliveira Guimarães', Maria Helena Miguez da Rocha Leão², \\ Carlos José Pimenta ${ }^{3}$, Larissa de Oliveira Ferreira ${ }^{3}$, Eric Batista Ferreira ${ }^{4}$
}

\begin{abstract}
This study deals with development of a "dulce de leche" (DL) with coffee, with low caloric content and functional properties. Through rotational central composite design, eleven DLs were formulated with different polydextrose and sucralose levels. The results were analyzed by means of response surface and ANOVA. The addition of polydextrose led to the increase in moisture and water activity and reduction in the ash and soluble solids contents. In the formulations with greater levels of sucralose and polydextrose, there was an increase in the ash, acid and fiber content. Greater yield was achieved with greater concentrations of polydextrose and less substitution of sucrose by sucralose, allowing development of a new functional product with low caloric content.
\end{abstract}

Index terms: Prebiotics, polydextrose, new product development.

\section{RESUMO}

Esta pesquisa trata do desenvolvimento de um doce de leite com café, de baixo valor calórico e funcional. Por meio do delineamento composto central rotacional, foram formulados onze doces de leite com diferentes níveis de polidextrose e sucralose. Os resultados foram analisados por meio de superfície de resposta e ANOVA. A adição da polidextrose influenciou no aumento da umidade e atividade de água e redução nos teores de cinza e sólidos solúveis. Nas formulações com maiores níveis de sucralose e polidextrose, houve incremento no teor de cinza, acidez e fibras. Maiores rendimentos foram alcançados com maiores concentrações de polidextrose e menor substituição de sacarose por sucralose, possibilitando o desenvolvimento de um novo produto de baixo valor calórico e funcional.

Termos para indexação: Prebiótico, polidextrose, desenvolvimento de produto novo.

\section{(Received in march 26, 2012 and approved in april 18, 2012)}

\section{INTRODUCTION}

Increased dissemination of information on the relationship between foods and chronic diseases, as well as health and longevity, has led to consumer awareness in relation to food quality. The trend is that traditional products rich in calories, fats and sugars gradually come to be substituted by products in the light, diet and functional lines which meet these requirements and maintain the characteristics of the conventional products in terms of texture, flavor and aroma.

Among the traditional products that typically have high levels of sugars, fats and calories is dulce de leche (DL), a highly consumed product in Latin America, especially in Brazil, whose caloric value can reach over $300 \mathrm{Kcal} / 100 \mathrm{~g}$. For preparation of alternative DLs, there are raw materials with functional and structural properties that may result in a reduction of caloric content.
Coffee has been considered by the medicalscientific community as a functional or even nutraceutical beverage. That is because the roasting process results in the production of some biologically active substances which exercise benefits to human health, such as chlorogenic acids, trigonelline and caffeine (ABRAHÃO et al., 2008; ARAÚJO; MANCINI FILHO, 2006).

Polydextrose, recognized as a dietary fiber, has high hygroscopicity and its application is appropriate for formulations of foods that have undergone removal of soluble ingredients such as sucrose. A large advantage offered by polydextrose is its low caloric value in comparison to carbohydrates (polydextrose $=1 \mathrm{kcal} \mathrm{g}^{-1}$ and carbohydrate $=4 \mathrm{kcal} \mathrm{g}^{-1}$ ). From the functional perspective, polydextrose provides physiological benefits from soluble dietary fibers, such as the production of short chain fatty acids, reduction of intestinal transit time, decreased carcinogen production,

\footnotetext{
1Universidade Federal do Rio de Janeiro/UFRJ - Departamento de Ciência de Alimentos - Endereço completo - 21910-900 - Rio de Janeiro - RJ - Brasil ivinagui@gmail.com

2Universidade Federal do Rio de Janeiro/UFRJ - Departamento de Ciência de Alimentos - Rio de Janeiro - RJ - Brasil

3Universidade Federal de Lavras/UFLA - Departamento de Ciência dos Alimentos/ DCA - 37200-000 - Lavras - MG - Brasil

${ }^{4}$ Universidade Federal de Alfenas/UNIFAL - Instituto de Ciências Exatas - Alfenas - MG - Brasil
} 
as well as maintenance of intestinal microbiota (GOMES et al., 2007; PRONCZUK; HAYES, 2006).

Sucralose, a sucrose chlorination derived sweetener, has technological properties favorable to the confection of candied products or sweet pastes, such as high thermal stability, solubility in a aqueous or acidic medium, and lack of a bitter or metallic residual flavor.

It is worth emphasizing that formulations with reduced calorie content are generally more complex and must be balanced for the product to acquire good consistency, flavor, sweetness and yield, characteristics of the traditional version. Therefore, the purpose of this study was to analyze the effect of concentration of dietary fiber and substitution of sucrose by sucralose in DLs with coffee by means of physical and chemical analyses.

\section{MATERIAL AND METHODS}

\section{Raw material}

Standard homogenized and pasteurized cow's milk, of the Ipê brand, was supplied by the Cooperativa Agrícola Alto Rio Grande (Upper RioGrande Agricultural Cooperative) - CAARG (Minas Gerais, Brazil). Mild instant coffee (Nescafé-Nestlé) and crystal sugar (Caeté) were purchased on the retail market of Lavras, Minas Gerais, (Brazil). The sucralose Splenda was granted by Tovani Benzaquen Ingredientes Ltda. The polydextrose Litesse Powder was purchased from Danisco Brasil Ltda. Sodium bicarbonate PA (Biotec) and sodium citrate PA-ACS (Synth) was used. The chemical reagents used offered the analytical degree of purity required by the analytical methods used.

\section{Formulations}

For manufacture of the light DLs, the following ingredients were used: pasteurized skim milk (fat content: $0.2 \%$ ) from the same batch, crystal type sugar and sucralose, sodium bicarbonate, polydextrose, sodium citrate and $1 \%$ instant coffee, suggested by Ferreira (2011) as the most acceptable concentration from the taste testers. For the traditional version of DL, whole pasteurized milk from the same batch, crystal sugar, sodium bicarbonate, sodium citrate and $1 \%$ instant coffee were used. The quantity of sucralose added was calculated in such a way that its sweetening power was equivalent to a DL formulated with $20 \%$ (w/w) of sucrose content. The coffee concentration was determined in relation to the quantity of milk. The formulation used for confection of the DLs (Table 1) was based on the formulation suggested by Perrone et al. (2007).

\section{Milk analysis}

The milk was analyzed for acidity using the titration method with Dornic solution (BRASIL, 2006). After carrying out analysis, calculation was made for reduction of acidity of the milk to $10^{\circ}$ Dornic ( $1^{\circ}$ Dornic is equivalent to $0.1 \mathrm{~g}$ of lactic acid), in accordance with the formula used by Martins and Lopes (1981).

The total solids content of the milk was calculated in accordance with the formula of Furtado, presented by Pereira et al. (2000). For this purpose, the fat content was directly determined using the Gerber butyrometer; density and temperature were evaluated by means of a lacto density meter at $15^{\circ} \mathrm{C}$ (PEREIRA, 2000).

Table 1 - Ingredients used in along the formulations of DLs with coffee.

\begin{tabular}{cccccccc}
\hline Formulations & Milk $(\mathrm{L})$ & Sucralose $(\mathrm{g})$ & Sucrose $(\mathrm{g})$ & Polydextrose $(\mathrm{g})$ & $\begin{array}{c}\text { Instant } \\
\text { coffee }(\mathrm{g})\end{array}$ & $\begin{array}{c}\text { Sodium } \\
\text { citrate }(\mathrm{g})\end{array}$ & $\begin{array}{c}\text { Sodium } \\
\text { bicarbonate }(\mathrm{g})\end{array}$ \\
\hline 1 & 3 & 0.2500 & 450.00 & 60.0 & 30 & 2.4 & 1.68 \\
2 & 3 & 0.5000 & 300.00 & 60.0 & 30 & 2.4 & 1.68 \\
3 & 3 & 0.2500 & 450.00 & 120.0 & 30 & 2.4 & 1.68 \\
4 & 3 & 0,5000 & 300.00 & 120.0 & 30 & 2.4 & 1.68 \\
5 & 3 & 0.1987 & 480.78 & 90.0 & 30 & 2.4 & 1.68 \\
6 & 3 & 0.5513 & 269.22 & 90.0 & 30 & 2.4 & 1.68 \\
7 & 3 & 0.3750 & 375.00 & 47.7 & 30 & 2.4 & 1.68 \\
8 & 3 & 0.3750 & 375.00 & 132.3 & 30 & 2.4 & 1.68 \\
9 & 3 & 0.3750 & 375.00 & 90.0 & 30 & 2.4 & 1.68 \\
10 & 3 & 0.3750 & 375.00 & 90.0 & 30 & 2.4 & 1.68 \\
11 & 3 & 0.3750 & 375.00 & 90.0 & 30 & 2.4 & 1.68 \\
12 & 3 & - & 600.00 & - & 30 & 2.4 & 1.68 \\
\hline
\end{tabular}

Ciênc. agrotec., Lavras, v. 36, n. 2, p. 195 -203, mar./abr., 2012 


\section{Preparation of the DLs}

The DLs were eleborated following an adaptation of the technology described by Martins and Lopes (1981) for manufacture of DL. The main modifications were: partial substitution of sucrose by sucralose, and addition of polydextrose and instant coffee.

The milk was placed in an open stainless steel pot with a mechanical mixing blade with a working capacity of 20 liters of milk. During heating, the sucrose/sucralose, sodium citrate and polydextrose previously dissolved in part of the heated milk were added (BRASIL, 1997).

The different formulations were cooked until reaching a soluble solids content of $\pm 71^{\circ}$ Brix determined from preliminary tests by means of refractometer readings at $25^{\circ} \mathrm{C}$. Upon reaching the desired point, the heat was turned off and instant coffee previously diluted in hot water at a ratio of 1:1 (coffee:water) was added until obtaining a homogeneous mixture by means of a mechanical mixing blade. Afterwards, the DLs were bottled in glass containers while still hot, cooled in cold water and stored at room temperature for performance of analyses, in accordance with Ferreira (2011).

\section{Experimental design}

The experiments were performed in accordance with full factorial experimental design $2^{2}($ level \pm 1$)$ with the addition of 3 center points (level 0 ) and axial points (levels \pm 1.41 ), for a total of 11 tests. The value of a is a function of the number of independent variables $(\mathrm{k})$, being defined by equation 1(BARROS NETO et al., 1995):

$\alpha=\left(2^{\mathrm{k}}\right)^{1 / 4}$

As there are two independent variables, the value of $\alpha$ is 1.41 .

The ranges of variation between the upper $(50.13 \%$ $\mathrm{X}_{1}$ and $\left.4,41 \% \mathrm{X}_{2}\right)$ and lower limits $\left(19.87 \% \mathrm{X}_{1}\right.$ and $1.59 \%$ $\mathrm{X}_{2}$ ) of each independent variable were established based on data from the literature and from preliminary tests undertaken, respecting legislation in effect in the country.

\section{Chemical composition and yield of DLs}

All analyses of the composition of pasteconsistency DLs were performed in triplicate and results were expressed in $\mathrm{g} / 100 \mathrm{~g}$ of sample.

Moisture content was determined by gravimetric analysis in accordance with recommendations of the physical-chemical methods for analysis of dairy products (BRASIL, 2006). The lipid content was determined by direct reading of the percentage of fat on the Gerber butyrometer, in accordance with the official methodology for determination of lipids in liquid milk (BRASIL, 2006). Protein was determined by the Kjeldahl method, multiplying the value of total nitrogen obtained by the conversion factor 6.38 (AOAC, 2006). The ash content (fixed mineral residue) was measured by gravimetric analysis after calcinations of the samples in a muffle furnace (AOAC, 2006). Total sugars were determined by the Antrona method in accordance with Dische (1962), using the spectrophotometer reading at $620 \mathrm{~nm}$. The dietary fiber content was calculated theoretically, taking into consideration that the polydextrose used has $90 \%$ total fibers, this data being obtained from the suppliers. The caloric value of the samples was determined in an adiabatic bomb calorimeter model Parr 1261 (Parr Instruments Co.). The results obtained from the bomb calorimeter were expressed in $\mathrm{kcal} / 100 \mathrm{~g}$.

The yield of the different formulations of the DLs was evaluated using the formula proposed by Martins and Lopes (1981):

$\mathrm{R}=(\mathrm{SM} \times 100) / \mathrm{SD}$, where:

$\mathrm{R}=\operatorname{yield}(\%)$

$\mathrm{SM}=$ total solids of all ingredients $(\mathrm{g})$; and

$\mathrm{SD}=$ total solids of the $\mathrm{DL}(\mathrm{g})$

Total solids were calculated by the difference between 100 and the moisture content, with the results being expressed in $\mathrm{g}$ of total solids $/ 100 \mathrm{~g}$ of sample (BRASIL, 2006).

\section{Physical and physical-chemical analyses of the DLs}

For determination of the parameters of color $\mathrm{L} *$ (luminosity), $\mathrm{a}^{*}$ (intensity of red) and $\mathrm{b}^{*}$ (intensity of yellow) the bench top colorimetry device, Konica Minolta brand spectrophotometer model CM-5, was used. Readings of the parameters were based on CIELab systems, with a $10^{\circ}$ observation angle, D65 illuminant with specular component included.

Hydrogenionic potential was determined by the electroanalytic method through the reading of the digital $\mathrm{pH}$ meter Tecnal R Tec 3MP, in accordance with Brasil (2006).

Total titratable acidity was determined by titration with a $0.1 \mathrm{~N}$ sodium hydroxide solution $(\mathrm{NaOH})$, using phenolphthalein at $1 \%$ as an indicator, with the result being expressed in percentage of lactic acid per $100 \mathrm{~g}$ of sample, in accordance with the methodology proposed by Brasil (2006). 
Determination of soluble solids was performed by refractometry, using the digital refractometer ATAGO PR100 with automatic temperature compensation at $25^{\circ} \mathrm{C}$ (AOAC, 2006). The ${ }^{\circ}$ Brix reading was used as a measurement of the total soluble solids content.

Water activity of the DLs was evaluated on the AquaLab model 3 TE series 3B v. 3.0 device, with readings at a controlled temperature of $25 \pm 0.3^{\circ} \mathrm{C}$.

\section{Evaluation of instrumental texture profile}

Texture profile analysis (TPA) was performed in a General Foods Texturometer, model TA.XT2i (Stable Micro Systems), using the Warner-Bratzler shear probe, with the data being automatically calculated by the software XTRAD Texture Expert based on force curves $(\mathrm{N})$ versus time (s) generated during the test. The parameters obtained were: hardness $(\mathrm{N})$, cohesiveness, elasticity $(\mathrm{mm})$, adhesiveness $(\mathrm{N} / \mathrm{s})$ and gumminess $(\mathrm{N})$.

Analyses were performed on the DLs within the packaging itself (250g capacity). For the tests, the following parameters were adopted: pretest speed: $2.0 \mathrm{~mm} / \mathrm{s}$; test speed: $1.0 \mathrm{~mm} / \mathrm{s}$; posttest speed: $2.0 \mathrm{~mm} / \mathrm{s}$; penetration: $10.0 \mathrm{~mm}$; time: $0.5 \mathrm{~s}$; contact force: $5.0 \mathrm{~g}$; probe: $20.0 \mathrm{~mm}$ acrylic cylinder (P20).

\section{Analysis of results}

After obtaining results, the response surface methodology was used to evaluate the effect of the concentrations of polydextrose and sucralose/sucrose on the physical and physical-chemical variables. The quadratic model was used for the purpose of evaluating the effect of the factors, including the interaction effect.

$$
Y=\beta_{0}+\beta_{1} x_{1}+\beta_{2} x_{2}+\beta_{12} x_{1} x_{2}+\beta_{11} x_{1}^{2}+\beta_{22} x_{2}^{2}+\varepsilon
$$

in which $\beta n$ are the regression coefficients, $\mathrm{Y}$ is the response under study (physical and physical-chemical parameters), $x_{1}, x_{2}$ are the coded independent variables (percent of substitution of sucrose by sucralose and percent of addition of polydextrose) and $\varepsilon$ the experimental error.

The results of the dependent variables were treated by multiple regression analysis of the response surface methodology, and analysis of variance was applied to test the suitability of the models. The significance of regression by the $\mathrm{F}$ test and by the coefficient of determination $\left(\mathrm{R}^{2}\right)$ was observed in the models, thus verifying if the model represented a degree of adjustment suited to the experimental data.
To visualize the effects of the independent variables and of their interactions on the responses evaluated, a response surface graph was constructed when analysis of variance proved to be significant. Processing the data was performed using the software package Statistica 5.1 for Windows (Statsoft, Inc., OK, USA).

\section{RESULTS AND DISCUSSION}

The data on chemical composition and yield of the different formulations of the DLs are presented in table 2 .

In the present study, it was observed that the moisture contents $(12.45 \%$ to $21.70 \%)$ are within the reference parameters of Brazilian Food Regulation (Portaria) no. 354 of September 4, 1997 (BRASIL, 1997), where it is required that DL may contain a maximum moisture content of $30 \%$. Upon studying the chemical composition of the DLs, Braga et al. (2012) and Torres et al. (2000) found mean values of around 26\% moisture. Demiate et al. (2001), upon evaluating commercial samples of DL, found values that ranged from 19.0 to $37.2 \%$.

The paste-consistency DL must contain at least $5 \%(w / w)$ protein content (BRASIL, 1997). As may be observed in table 2 , the protein values found for the light functional DLs are in accordance with legislation in effect (9.87\% to $12.51 \%$ ). The commercial samples of DL evaluated by Demiate et al. (2001), exhibited protein contents ranging from $1.4 \%$ to $13.9 \%$, demonstrating the lack of standardization of the products, including levels less than that required by Brazilian legislation. Braga et al. (2012), evaluating DLs with the addition of extract of annatto seeds, found protein contents that ranged from $7.09 \%$ to $7.67 \%$.

The fat content must range from 6.0 to $9.0 \%(\mathrm{w} / \mathrm{w})$; however, the contents found were less $(0.50$ to $1.00 \%)$. This occurred due to the fact of being a light product, substituting whole milk for skim milk. Madrona et al. (2009) did not observe a significant difference in the fat content when the whey concentration varied, due to previous standardization performed on the milk and on the milk and whey combinations used in the manufacture of DLs. Braga et al. (2012), found lipid levels in DL with extract of annatto seeds going beyond the values stipulated in legislation, which was explained due to the fact of the extract of annatto seeds having been confected with an emulsion containing soybean oil. The authors, moreover, suggest using skim milk to reduce the lipid concentration to keep it within the proportions established by Brazilian legislation, which was done in the present study. 
Table 2 - Mean values and standard deviation obtained for the variables: moisture, protein, lipids, total sugars, ash, caloric value and yield.

\begin{tabular}{|c|c|c|c|c|c|c|c|c|c|}
\hline \multicolumn{2}{|c|}{ Formulations } & $\mathrm{M}(\%)$ & $\mathrm{CP}(\%)$ & $\mathrm{L}(\%)$ & TS $(\%)$ & $\mathrm{A}(\%)$ & CV (Kcal/100g) & $\mathrm{DF}(\%)$ & $\mathrm{Y}$ \\
\hline \multirow{2}{*}{1} & $\mathrm{ME}$ & 15.17 & 11.02 & 1.00 & 44.43 & 2.32 & 229 & 1.8 & 38.72 \\
\hline & SD & 0.34 & 0.28 & 0.00 & 0.18 & 0.03 & 0.00 & 0.00 & 0.00 \\
\hline \multirow{2}{*}{2} & ME & 15.00 & 9.87 & 1.00 & 43.04 & 2.70 & 203 & 1.8 & 26 \\
\hline & SD & 0.71 & 0.14 & 0.00 & 0.26 & 0.09 & 0.00 & 0.00 & 0.00 \\
\hline \multirow{2}{*}{3} & ME & 19.51 & 10.99 & 0.50 & 44.57 & 2.33 & 186 & 3.6 & 36.4 \\
\hline & SD & 1.02 & 0.02 & 0.00 & 0.28 & 0.23 & 0.00 & 0.00 & 0.00 \\
\hline \multirow{2}{*}{4} & ME & 21.70 & 10.74 & 1.00 & 46.88 & 2.37 & 214 & 3.6 & 30.84 \\
\hline & SD & 0.64 & 0.10 & 0.00 & 1.90 & 0.10 & 0.00 & 0.00 & 0.00 \\
\hline \multirow{2}{*}{5} & ME & 16.64 & 12.32 & 0.50 & 43.90 & 2.24 & 284 & 2.7 & 35.0 \\
\hline & SD & 0.60 & 0.09 & 0.00 & 0.50 & 0.18 & 0.00 & 0.00 & 0.00 \\
\hline \multirow{2}{*}{6} & ME & 16.08 & 12.51 & 1.00 & 42.15 & 2.84 & 238 & 2.7 & 26.3 \\
\hline & SD & 0.53 & 0.05 & 0.00 & 0.15 & 0.06 & 0.00 & 0.00 & 0.00 \\
\hline \multirow{2}{*}{7} & $\mathrm{ME}$ & 12.45 & 10.95 & 1.00 & 42.85 & 2.62 & 283 & 1.4 & 28.3 \\
\hline & SD & 0.42 & 0.07 & 0.00 & 0.57 & 0.04 & 0.00 & 0.00 & 0.00 \\
\hline \multirow{2}{*}{8} & $\mathrm{ME}$ & 20.22 & 11.75 & 1.00 & 40.33 & 2.15 & 279 & 3.9 & 40.0 \\
\hline & SD & 0.72 & 0.16 & 0.00 & 0.79 & 0.01 & 0.00 & 0.00 & 0.00 \\
\hline \multirow{2}{*}{9} & ME & 14.35 & 12.05 & 0.50 & 43.78 & 2.49 & 300 & 2.7 & 30.0 \\
\hline & SD & 0.66 & 0.19 & 0.00 & 0.43 & 0.08 & 0.00 & 0.00 & 0.00 \\
\hline \multirow{2}{*}{10} & $\mathrm{ME}$ & 15.51 & 11.65 & 0.50 & 43.69 & 2.45 & 240 & 2.7 & 30.3 \\
\hline & SD & 0.33 & 0.11 & 0.00 & 0.81 & 0.14 & 0.00 & 0.00 & 0.00 \\
\hline \multirow{2}{*}{11} & $\mathrm{ME}$ & 15.61 & 11.59 & 1.00 & 41.45 & 2.36 & 303 & 2.7 & 30.4 \\
\hline & SD & 0.46 & 0.09 & 0.00 & 0.66 & 0.03 & 0.00 & 0.00 & 0.00 \\
\hline
\end{tabular}

$\mathrm{ME}=$ mean; $\mathrm{SD}=$ standard deviation; $\mathrm{M}=$ moisture $\mathrm{CP}=$ crude protein $\mathrm{L}=$ lipids; $\mathrm{TS}=$ total sugar; $\mathrm{A}=$ ash $\mathrm{CV}=$ caloric value; $\mathrm{DF}=$ dietary fiber; $\mathrm{Y}=$ yield.

In table 2 , it may be observed that in relation to ash content, the DLs exhibited contents a little above that which is permitted $(2.0 \% \mathrm{w} / \mathrm{w})$. Demiate et al. (2001) observed a variation from $0.8 \%$ to $2.1 \%$ of ash content in commercial paste-consistency DLs. According to the same authors, the ash content is one of the indicators of the presence of milk in the product because it is a constant value in this raw material. As the addition of sodium bicarbonate is allowed in DL production, as well as some other salts, there may be high values of ash content.

By the response surface methodology, the factors under study (addition of polydextrose and substitution of sucrose by sucralose) did not significantly influence $(\mathrm{p} \geq 0.05)$ protein, lipid, and total sugar content and the caloric value of the DLs.
Through the response surface presented in figure 1a, it may be observed that the increase in the percent of addition of polydextrose contributed to the increase in DL moisture content. According to Maier et al. (1993), soluble fibers tend to form gels in contact with water and thus lead to an increase in moisture retention.

The ash content of the samples was significantly affected $(\mathrm{p} \leq 0.01)$ by the factor of substitution of sucrose by sucralose (L) and by the factor of concentration of addition of polydextrose (L) (Figure 1b). According to Figure $1 b$, the greater the concentration of sucralose, the greater the ash content, in contrast to the polydextrose content, in which the greater the concentration, the less the ash content. This may be associated with higher water retention and consequent dilution of mineral residue. 
(a)

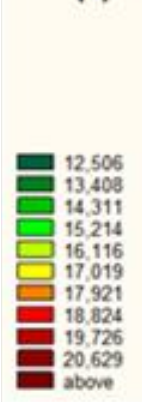

(c)

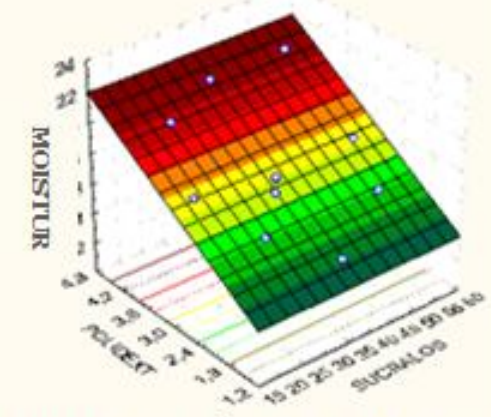

$\mathrm{M}=8.29+2.75 \mathrm{X}^{2} \quad \mathrm{R} 2=0.7887$

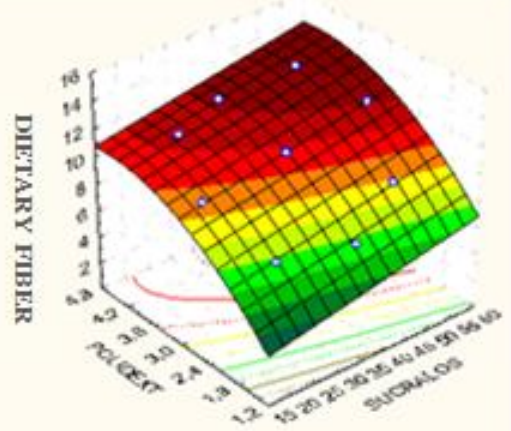

(b)

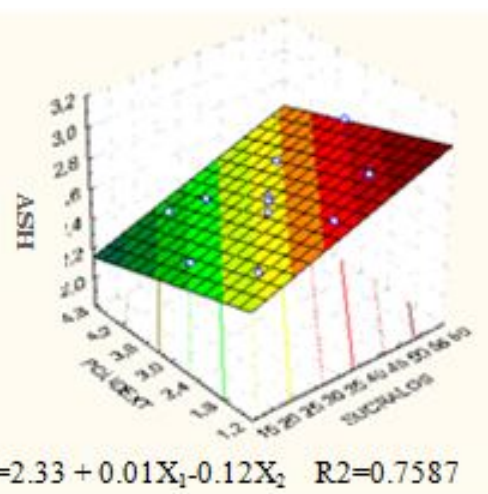

(d)

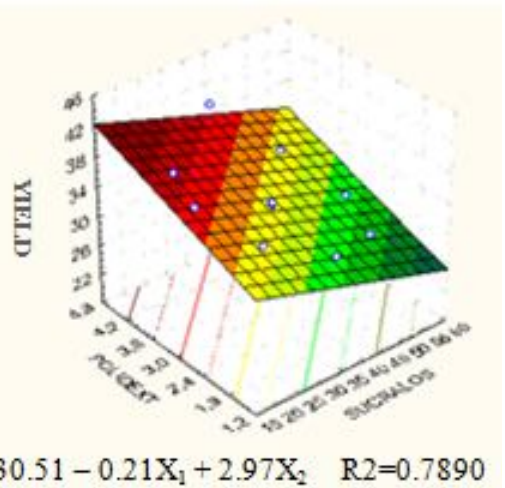

Figura 1 - (a): Response surface and regression model for moisture (M); (b): Response surface and regression model for ash (A); (c): Response surface and regression model for dietary fiber (DF); (d): Response surface and regression model for yield (Y).

In relation to dietary fiber content, it was significantly affected $(\mathrm{p} \leq 0.01)$ by the factor of substitution of sucrose by sucralose (L) and by the factor of concentration of addition of polydextrose (L) (Figure 1c). The effects of substitution of sucrose by sucralose and of the increase of polydextrose were positive; in other words, the increase of sucralose culminated in the need for increasing the texture of the DL, that is, addition of polydextrose, which resulted in greater dietary fiber content. According to Brazilian Food Regulation, solid foodstuffs must contain at least $3 \mathrm{~g}$ of dietary fiber $/ 100 \mathrm{~g}$ product to be able to claim status as a source of dietary fiber (BRASIL, 1998). These products thus exhibit desirable physiological characteristics, considering the presence of polydextrose, a substance with proven prebiotic activity.

The yield of the DLs was significantly affected $(p \leq 0.01)$ by the factor of substitution of sucrose by sucralose (L) and by the factor of concentration of addition of polydextrose (L) (Figure 1d). Higher yields were achieved when the DLs were confected with greater concentrations of polydextrose and less substitution of sucrose by sucralose (Figure 1d). This fact may be explained due to polydextrose lending consistency and texture and having a high degree of hygroscopicity (GOMES et al., 2007), which ended up being reflected in greater moisture content and consequently greater yield. In regard to sucrose, it needed to be added in higher quantity to the DL to provide sweetness, culminating in more consistency and yield, in contrast to sucralose, a sweetener which is 600 times sweeter than sucrose, and so in a smaller quantity is already able to achieve the expected sweetness.

By the response surface methodology, the factors under study (addition of polydextrose and substitution of sucrose by sucralose) did not significantly influence $(\mathrm{p} \geq 0.05)$ the $\mathrm{pH}$ and the color of the DLs.

The $\mathrm{pH}$ values found in this study ranged from 6.44 to 6.80 , similar to the study of Milagres et al. (2010), who found $\mathrm{pH}$ variation from 6.22 to 6.46 for DLs confected with sucrose, sucralose and mixture of cyclamate, saccharin and sorbitol. These $\mathrm{pH}$ values were also similar to those found by Braga et al. (2012) for the DLs with or without the

Ciênc. agrotec., Lavras, v. 36, n. 2, p. 195 -203, mar./abr., 2012 
addition of extract of annatto, which ranged from 6.5 to 6.9. Ferreira (2011) explained the lower value of $\mathrm{pH}$ and higher acid content in relation to other studies due to the presence of coffee.

In respect to color, Ferreira (2011) observed that the greater the percentage of substitution of milk by whey and the increase in addition of coffee to the formulation of the DL, the less intensity of yellow color and intensity of luminosity $\left(\mathrm{L}^{*}\right)$.

Higher acidity values in the DLs were observed when there was greater substitution of sucrose by sucralose (Figure 2a).

The percent of polydextrose (L) had a significant effect $(\mathrm{p} \leq 0.01)$ on the soluble solids content of the DLs. As may be observed in Figure $2 b$, the greater the concentration of polydextrose added to the DL, the less the content of soluble solids. This result may be related to the greater moisture present in the DLs that had a greater addition of polydextrose, which resulted in DLs with a lower soluble solids content.

The percentage of polydextrose (L) had a significant influence $(\mathrm{p} \leq 0.01)$ on the water activity of the DLs. The effect of the polydextrose factor was observed to be positive; in other words, with an increase in the percent of addition of polydextrose, the water activity of the DLs increased. According to the adjusted model, a response surface was constructed (Figure 2c) for evaluation of the water $\operatorname{activity}\left(\mathrm{A}_{\mathrm{w}}\right)$.

The sucralose and polydextrose factors, and the sucralose and polydextrose interactions did not have a significant influence $(p \geq 0.05)$ on the texture of the DLs. Ferreira (2011) also did not find significance for the variables of hardness, adhesiveness, elasticity, cohesiveness and gumminess of the DLs confected with different percentages of addition of whey and coffee.
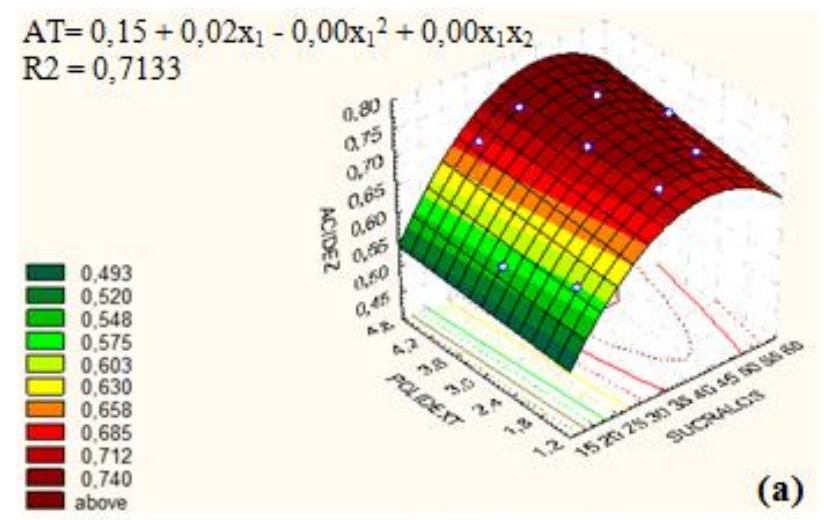

(a)

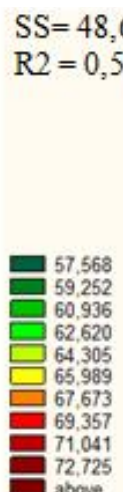

$\mathrm{SS}=48,63+0,88 \mathrm{x}_{1}-0,01 \mathrm{x}_{1}^{2}+8,07 \mathrm{x}_{2}-1,00 \mathrm{x}_{2}^{2}-0,11 \mathrm{x}_{1} \mathrm{x}_{2}$ $\mathrm{R} 2=0,5392$

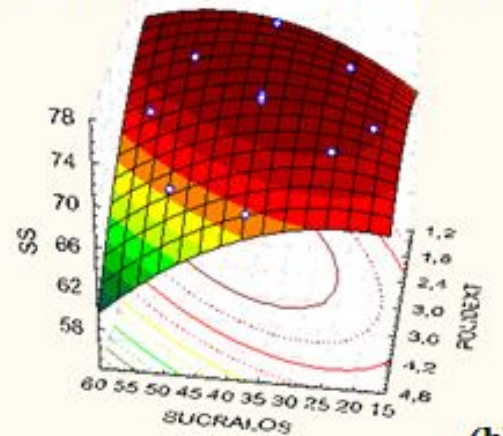

(b)

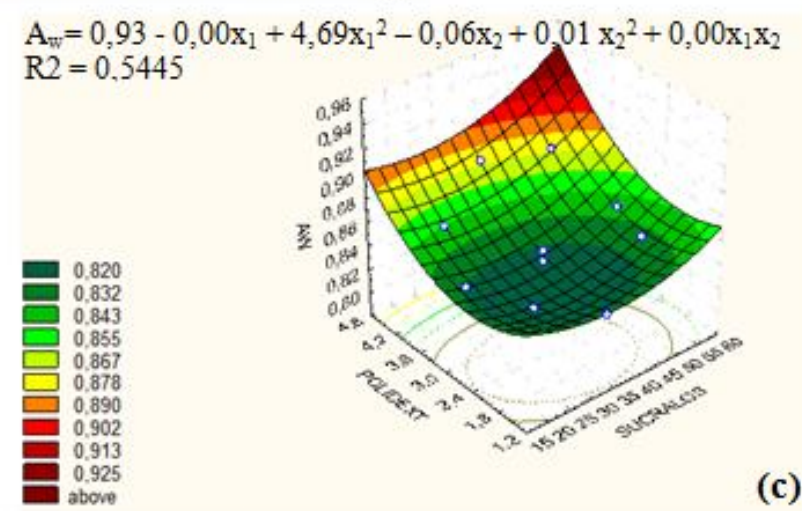

Figura 2 - (a): Response surface and regression model for titratable acidity (AT); (b): Response surface and regression model for soluble solids (SS); (c): Response surface and regression model for water activity $\left(\mathrm{A}_{\mathrm{w}}\right)$. 


\section{CONCLUSIONS}

The addition of polydextrose had an influence on the increase of moisture content and water activity of the DLs and reduction in their ash and soluble solids content. The increase in the percentage of substitution of sucrose by sucralose increased the ash content and acidity of the DLs and culminated in the need to increase the consistency of the DL, that is, the need to add polydextrose, which resulted in greater dietary fiber contents. Higher yields were reached when the DLs were confected with greater concentrations of polydextrose and less substitution of sucrose by sucralose. In general, it may be observed that the use of polydextrose and sucralose does not have a high influence on the quality of the DL, thus constituting an excellent alternative for improvement of the nutritional quality of DL.

\section{REFERENCES}

ABRAHÃO, S. A. et al. Compostos bioativos em café integral e descafeinado e qualidade sensorial da bebida. Pesquisa Agropecuária Brasileira, Brasília, v.43, n. 12, p.1799-1804, 2008.

ARAÚJO, F.A.; MANCINI-FILHO, J. Compostos bioativos do café e seus benefícios à saúde. Revista Higiene Alimentar, São Paulo, v.20, p.60-65, 2006.

ASSOCIATION OF OFFICIALANALYTICAL CHEMISTS. Official methods of analysis of the association of analitical chemists. 18th ed. Arlington, 2006. 1141p.

BARROS NETO, B., SCARMINIO, I. S., BRUNS, R. E. Planejamento e otimização de experimentos. Campinas: Unicamp, 1995. p. 1-299.

BRAGA, A. J. S. et al. Composição nutricional e teor de carotenóides de doces de leite adicionados de extrato de urucum (Bixa orellana). Revista Ciências em Saúde, Itajubá, v.2, n.1, p.28-34, 2012.

BRASIL. Ministério da Agricultura, Pecuária e Abastecimento. Portaria n 3 354, de 4 de setembro de 1997. Regulamento da Inspeção Industrial e Sanitária de Produtos de Origem Animal. Diário Oficial da República Federativa do Brasil, Brasília, DF. Disponível em: <http:// sistemasweb.agricultura.gov.br/>. Acesso em: 5 jul. 2011.

BRASIL. Ministério da Agricultura, Pecuária e Abastecimento. Instrução Normativa ${ }^{\circ}$ 68, de 12 de dezembro de 2006. Dispõe dos métodos analíticos oficiais físico-químicos, para controle de leite e produtos lácteos. Diário Oficial da República Federativa do Brasil, Brasília, DF. Disponível em: <http://sistemasweb.agricultura. gov.br/>. Acesso em: 3 jul. 2011.

BRASIL, Ministério da Saúde. Secretaria de Vigilância Sanitária. Portaria n ${ }^{\circ}$ 27, de 16 de janeiro de 1998.

Regulamento técnico referente à informação nutricional complementar (Declarações relacionadas ao conteúdo de nutrientes), constantes do anexo desta Portaria. Diário Oficial da República Federativa do Brasil, Brasília, DF. Disponível em: <http://http://portal.anvisa.gov.br/wps/ wcm/connect/9180ca00474581008d31dd3fbc4c6735/ PORTARIA_27_1998.pdf?MOD=AJPERES/ > . Acesso em: 3 jan. 2012.

DEMIATE, I. M., KONKEL, F. E., PEDROSO, R. A. Avaliação da qualidade de amostras comerciais de doce de leite pastoso: composição química. Ciência e Tecnologia de Alimentos, Campinas, v.21, n.3, p.108-114, 2001.

DISCHE, Z. General color reactions. In: WHISTLEr, R. L., WOLFRAM, M. L. Carbohydrate chemistry. New York: Academic Press, 1962, p. 477-512.

FERREIRA, L. O. et al. Sensory evaluation of "dulce de leche" with coffee and whey using different affective data analysis methods. Ciência e Tecnologia de Alimentos, Campinas, v.31, n.4 p. 998-1005, 2011.

GOMES, C. R. et al. Inûuência de diferentes agentes de corpo nas características reológicas e sensoriais de chocolates diet em sacarose e light em calorias. Ciência e Tecnologia de Alimentos, v. 27, n.3, p. 614-623, 2007.

MADRONA, G. S. et al. Estudo do efeito da adição de soro de queijo na qualidade sensorial do doce de leite pastoso. Ciência e Tecnologia de Alimentos, Campinas, v.29, n.4, p. 826-833, 2009.

MAIER, H. et al. Guar, locust bean, tara and fenugreek gums. In: WHISTLER, R.L., BEMILLER, J.N. Industrial gums: polysaccharides and their derivatives. New York: Academic Press, 1993, p. 181-226.

MARTINS, J. F. P., LOPES, C. N. Doce de leite: aspectos da tecnologia de fabricação. Campinas: Instituto de Tecnologia de Alimentos, 1981, p. 1-37. 
MILAGRES, M. P. et al. Análise físico química e sensorial de doce de leite produzido sem adição de sacarose. Revista Ceres, Viçosa, v.57, n. 4, p. 439-445, 2010.

PEREIRA, D.B.C. et al. Físico-química do leite e derivados: métodos analíticos. 2 ed. Juiz de Fora: Oficina de Impressão, 2000. 190 p.

PERRONE, I. T., QUEIROZ, F., ABREU, L. R. Efeito da nucleação secundária sobre a cristalização do doce de leite. Revista do Instituto de Laticínios Cândido Tostes, Juiz de Fora, v.61, p.01-04, 2007.

PRONCZUK, A., HAYES, K.C. Hypocholesterolemic effect of dietary polydextrose in gerbils and humans. Nutrition Research, v.26, n.1, p.27-31, 2006.

TORRES, E. A. F. S. et al. Composição centesimal e valor calórico de alimentos de origem animal. Ciência e

Tecnologia de Alimentos, Campinas, v.20, n.2, p.145-150, 2000. 